THURSDAY, OCTOBER IO, I9I8.

THE METALLURGY OF ZINC.

The Zinc Industry. By E, A. Smith. ("Monographs on Industrial Chemistry.") Pp. viii + 223. (London: Longmans, Green, and Co., I9I8.) Price ros. 6d. net.

RATHER more than four years ago an R American metallurgist, in opening a discussion on the metallurgy of zinc, said wittily: "It is a time-honoured custom to throw bricks at the zinc man. The accusation is that he has borrowed a lime kiln and a gas retort and part of a sulphuric acid plant, hitched them together, and spent the last fifty years in regarding with holy veneration the reactions which take place in that retort. The copper man who thinks of zinc as something with which copper is adulterated to make brass, and the iron man who regards it as a sort of paint for corrugated sheets, and the lead man whose opinion as to zinc is not fit for publication, have long felt that when two or three of the minor details of their respective metallurgies were put in orcier, they would take a few days and fix up zinc on a modern basis."

It is true that there have been no such spectacular changes in the metallurgy of this metal as were wrought in that of steel and copper by the introduction of converters. Nevertheless, it is quite untrue to state, as is sometimes done, that there has been no change in its metallurgy since the first Belgian furnaces were built in the early part of last century. The main reason why there has been ro revolutionary change is that the chemistry of zinc differs radically from that of the other metals, and that these differences control the type of apparatus that can be used.

In the first place, the temperature at which this metal is reduced by carbon from its oxide is considerably above its boiling-point under atmospheric pressure. It is, therefore, always produced as a vapour. In the second place, in order to obtain a merchantable product this vapour must be condensed at a temperature considerably above the melting-point of the metal. In practice, the temperature-range is from about $900^{\circ}$ to $45^{\circ} \mathrm{C}$. Above $900^{\circ} \mathrm{C}$. the vapour is not condensed at all; below $4 \mathrm{I} 5^{\circ} \mathrm{C}$. it freezes to a powder consisting of finely divided metal with between 6 and ro per cent. of oxide. More than this, the temperature necessary to condense the zinc as a liquid depends on the concentration of the vapour, and is lower the more dilute it is. Consequently the temperature of the condenser must be near that of the boiling-point of the metal at the end attached to the retort and very much lower at the opposite end. In the third place, the metal-vapour is extremely susceptible to oxidising influences, e.g. air, water-vapour, and even carbon dioxide. The charge must therefore at all stages contain a large excess of carbon, since the presence of even $0^{\prime} 25$ per cent. of carbon dioxide is sufficient to oxidise the metal in this condition; moreover, the volume of gas carrying the zinc must be kept as small as possible.
No other common industrial metal presents this combination of characteristics, which makes its smelting a by no means straightforward operation.

These and many other matters connected with the zinc industry are well set forth in Mr. E. A. Smith's book on the subject, which may be warmly commended to readers as giving, in the author's words, "a general survey of the development of the zinc industry and its present and possible future position in relation to the various metal industries of this country." In spite of the fact that the art of zinc extraction has been carried on in Great Britain for at least $\mathrm{I}_{50}$ years, its literature is very scanty, and Mr. Smith's book is therefore particularly timely, especially when it is remembered how gravely imperilled was the manufacture of certain munitions of war in this country by the cutting off of zinc supplies in Igr4. Mr. Smith deals successively with the rise and development of the industry in various centres of production, the sources of supply and marketing of the zinc ores, their smelting and other methods of extraction-electrothermal and electrolytic-the properties of the metal and its industrial applications as such and in the form of alloys, its commercial compounds and pigments, and, finally, with the future of the industry in this country. As he points out, British smelters in the last forty years have lagged far behind their rivals in Germany and Belgium. The latter have greatly improved their practice, not only by getting increased extractions from the ore, but also by reducing costs in fuel, retorts, and labour, and this superiority has reflected itself in the value of their shares as compared with those of British companies.

Mr. Smith's book is well written, well balanced, and accurate. Considering how much work has been done in recent years to render the electrolytic production of zinc a commercial success, he might with advantage have devoted more than six pages to this aspect of the industry, but this appears to the writer the only blemish in a very admirable and valuable book.

H. C. H. C.

\section{THE NATURE OF SOLUTION.}

The Nature of Solution. By Prof. Harry C. Jones. With a Biographical Sketch by Prof. E. E. Reid and Tributes by Profs. Arrhenius, Ostwald, and Woodward. Pp. xxiii +380 . (London: Constable and Co., Ltd., I917.) Price I2s. $6 d$. net.

THE late Prof. H. C. Jones's book on "The Nature of Solution " represents undoubtedly his best and ripest work. The scope and outlook of the book are almost unexpectedly wide, in view of the somewhat closely specialised character of the author's own researches and of the enormous mass of detail which the generosity of the Carnegie Institution enabled him to pile up in connection with some three or four problems relating to the nature of solution. All this mass of reiterated detail, which compelled him to publish from time to time papers summarising the results of other papers, has been left behind in the present book, and the whole treatment of the subject is broad and satisfying. It is particularly refreshing 